\title{
International Responsibility of the State for the Violation of International Military and Security Companies under the Rules of International Law
}

\author{
${ }^{1}$ Ayman Abu-alhaj (PhD) \\ Al-Balqa’ Applied University (BAU),Law Collage, Jordan
}

\begin{abstract}
The significance of this study stems from shedding light on the nature of the country's responsibility based on the acts of private military and security companies through the description of the staff of companies. This, however, in turn determines the referral of their acts or not to the countries that are parties to the armed conflicts. It also results to the consequence of the international responsibility of the country and the impacts of this responsibility. This study focuses on clarifying the concept of international responsibility of countries, determine the legal basis for this responsibility, identify the legal nature of the private military and security companies, and search for the legal rules governing them. This helps in determining the nature of their work and the reflection of these acts based on the extent of the official international responsibility for the contracted countries. It also seeks to identify the differentiation and the difference in the responsibility of the country based on the description of private military and security companies' staff. This is because they are a formation of their armed forces or they were not described as this. Also, the case of the responsibility of the country for the committed violations by persons or private groups was recognized by the country and was adopted as behaviors issued by it. In spite of that, this study will focus on the nature of the responsibility of the concerned country based on the referral of the acts of the staff of these companies or not as a self-assigned responsibility. In other words, there is an image to adapt the responsibility of the country in the case of the conditions available for the staff of these companies such as mercenaries, combatants, or civilians. The study concludes that there is a clear legal deficiency in the rules of international law whereas legal rules do not contain any legal provisions that deal with the responsibility of these companies regarding any violation committed during the course of their work and their military services in the conflict zones. Hence, many States have needed these companies to avoid the international responsibilities in case of the violation of international humanitarian law.
\end{abstract}

Keywords: International Responsibility, International Military and Security Companies, International Humanitarian Law

DOI: $10.7176 / \mathrm{JLPG} / 92-05$

Publication date: December $31^{\text {st }} 2019$

\section{Introduction}

Responsibility is described as a main pillar to any legal system. When a natural person is asked about his violations of national laws, then the subjects of international law would be held liable for their violations of the provisions of public international law(Yearbook of the International Law Commission, 2001, vol. II, Part Two, 2001, p. 33). However, this refers to what the international legal order accompanied based on the development of international relations and their organization, particularly in the field of the implementation of the agreed upon commitments by one of the parties.

According to the attention of the international community among countries' relations and the need for their commitment to the principles of public international law, and not violating the right of persons of the international community, the international community was led to control and determine the system of international responsibility of the country. Thus, this arises in the event that if the illegal act was attributed to the country or to one of its official bodies or different powers. This responsibility would be regarded as the direct international responsibility (Yearbook of the International Law Commission, 2001, vol. II, Part Two.30 ).

The armed forces of the country are considered to be one of the official bodies of the country. Therefore, the country is liable internationally to what these forces perpetrated. This includes violations of the rules of international law, particularly in the period of international conflicts and disturbance. Therefore, the country must abide by the rules of international humanitarian law and international human rights law (Abuel-haj, 2013, p173).

Due to the development of economic systems, countries - whether developing or developed - have sought to privatize many of their official institutions. This extended to include the privatization of vital and important sectors in the country, such as the security sectors. This was possible through their contract with some private security companies to perform some security functions, and with the growth and development of these private

\footnotetext{
1- This work has been carried out during sabbatical leave granted to the author (Ayman Abu-alhaj) from Al-Balqa' Applied University (BAU) during the academic year 2016/2017. Associated professor of international public law.
} 
companies and their spread. However, countries were able to expand through the help of these companies to include the military and security bodies directly, and through the training of military and security forces in the country. Furthermore, tasks related to maintenance and operating hi-tech types of weapons, which usually require high competencies for these tasks to be performed, were also assigned to these companies. This subject emphasizes the role of private military and security companies in regards to expansion such that countries became dependent on them directly during internal and international conflicts. Also, these companies provided fighting services to the conflicts' parties and also collect and analyze intelligence information about the conflicts' parties. With the growing role of these companies in wars, it is possible to say that contemporary wars have been regarded as the private sector wars.

Consequently, countries have taken this path in an attempt to avoid their international responsibility for any violation of the rules of public international law during armed conflicts. This has constituted a challenge to the international community in determining the nature of the act of these companies and their relationship with the contracting countries. Basically, this can be seen especially in the light of the violation of these companies based on the rules of international humanitarian law during their participation in armed conflicts. This challenge stems from the approach of the nature of military and private companies from the concept of mercenaries. Nevertheless, the rules of international law shortened the issue of mercenaries by describing them as individuals, and not morality units or companies. Thus, this can be seen as in the case of private military and security companies.

Based on the foregoing and on the basis of the country's responsibility for the acts of its military and security forces (i.e. in situations where countries resorted through international or internal conflicts in the private military and security companies instead of their military and security forces; in accordance to what the rules of public international law is characterized by -in particular the rules of international humanitarian law - ; ambiguity and lack of organizing the nature of the work of private military and security companies during armed conflicts and the nature of its relationship with the contracting country), we decided to search for these propositions to define the scope of international responsibility of countries for the acts Liability is described as a main pillar to any legal system, as when a natural person is asked about his violations of national laws, then the subjects of international law have been held liable for their violations of the provisions of public international law, which result as what the international legal order accompanied of development in the international relations and their organization, particularly in the field of the implementation of the agreed upon commitments by one of the party.

According to the attention of the international community among countries' relations and the need for their commitment to the principles of public international law, and not violating the right of persons of the international community, led the international community to control and determine the system of international liability of the country, which arise in the event that if the illegal act was attributed to the country or to one of its official bodies or different powers, this liability is known as the direct international liability.

The armed forces of the country is considered one of the official bodies of the country, and therefore the country is liable internationally of what these forces perpetrated of violations of the rules of international law, particularly in the period of international conflicts and disturbance, which the country must abide by the rules of international humanitarian law and international human rights law.

As a result of the development of economic systems, countries whether - developing or developed - have sought to privatize many of their official institutions, which extended to include the privatization of vital and important sectors in the country such as the security sectors, through their contract with some private security companies to perform some security functions, and with the growth and development of these private companies and their spread, countries headed to expand with the help of these companies to include the military and security bodies directly, and through the training of military and security forces in the country.

Furthermore, tasks related to maintenance and operating hi-tech types of weapons that need high competencies to perform these tasks.

This matter doesn't reach only to this extent, as the role of private military and security companies expanded so that countries became depending on them directly during internal and international conflicts, where these companies provide fighting services to the conflicts' parties and collect and analyze the intelligence information about the conflicts' parties, and with the growing role of these companies in wars, it was possible to say that contemporary wars have become described as the private sector wars.

In fact, countries are seeking through this in an attempt to avoid their international liability for any violation of the rules of public international law during armed conflicts. This has constituted a challenge to the international community in determining the nature of the act of these companies and their relationship with the contracting countries, especially in light of the violation of these companies to the rules of international humanitarian law during their participation in armed conflicts. This challenge stems from the approach of the nature of military and private companies from the concept of mercenaries, but the rules of international law shortened the issue of mercenaries by describing them as individuals, not morality units or companies, as in the case of private military and security companies. 
Based on the foregoing and on the basis of the country's liability for the acts of its military and security forces, and where countries resorted through international or internal conflicts to the private military and security companies instead of their military and security forces, and in accordance what the rules of public international law characterized by -and in particular the rules of international humanitarian law - ambiguity and lack of organizing the nature of the work of private military and security companies during armed conflicts and the nature of its relationship with the contracting country, we decided to search for these propositions to define the scope of international liability of countries for the acts of private military and security companies.

\section{The Significance of the Study and its Objectives:}

The significance of this study stems from shedding the light on the nature of the country's liability for the acts of private military and security companies, through the description of the staff of companies, which in turn determines the referral of their acts or not to the countries that are parties of the armed conflicts, and the consequent of the international liability of the country and the impacts of this liability.

As such, this study aims to achieve a set of objectives, which can be summarized in the following points:

- This study aims to clarify the concept of international liability of countries and determine the legal basis on which this liability is based.

- Identify the legal nature of the private military and security companies, and search in the legal rules governing them, to determine the nature of their work and the reflection of these acts on the extent to which the official international liability for the contracted countries.

- Define the duties and obligations of countries when contracting with private military and security companies.

- Identify the differentiation and the difference in the liability of the country in the description of private military and security companies' staff as they are a formation of their armed forces or not described as this, as well as the case of the liability of the country for the committed violations by persons or private groups recognized by the country and adopted as behaviors issued by it.

- The nature of the liability of the concerned country at the referral of the acts of the staff of these companies or not as a self - assigned liability, and in other words, the image to adapt the liability of the country in the case of the conditions available in the staff of these companies as mercenaries or combatants or civilians or not.

- Determine the outcome of the country's liability for the staff of these companies' acts if achieved, which include litigation before a competent judiciary, and the reparation of losses resulting from violations of these companies to the rules of international humanitarian law.

- Determine the methods and means that must be followed by the damaged before resorting to international claims for damages resulting from the act of private military and security companies.

\section{The problem of the Study and its Questions:}

The contemporary public international law trends not to prevent countries from contracting with international private military and security companies to perform some activities in international or internal armed conflicts, though the international humanitarian law points out the obligation of all countries to fulfill their legal obligations under international liability. But it is clear that when they do so, they remain liable for the fulfillment of the obligations imposed by the law, while explicitly the international humanitarian law treaties deal with some aspects of, or consequences of this liability, so what are stipulated of provisions in this regard, are dominated by a specific expression of the general rules concerning the direct liability borne by the countries in accordance with the provisions of public international law.

However, the contracting country may ask for the acts of the staff of these companies even if they were attributed to it indirectly, based on the due diligence, which requires that countries are obliged to take reasonable and serious measures to prevent private parties from violating the rules of international humanitarian law. This liability extends to include countries which the companies hold their nationality and countries that are relevant to these companies, especially, countries that the staff of these companies holds their nationality.

Accordingly, this study based on a main problem which is: What is the extent of countries' liability for the acts of private military companies and the scope of this liability and its legal basis?

In this regard, this problem raises many questions, which can be summarized as follows:

- What is the extent that the rules of international law dealing with regulating the work of private military and security companies?

- To what extent can the description of mercenaries apply to the staff of private military and security companies in accordance with the rules of international humanitarian law?

- What is the legal basis for the international liability of the country for the acts of the staff of private military and security companies, and the extent of the scope of this liability in terms of its involvement not only for the contracting country, but on the country that these companies or their staff holds their nationality?

- What are the consequences of the country's liability for the acts of private military and security companies' staff? 


\section{Methodology of the Study:}

The researcher in preparing this study depends on the following scientific methods:

1. The Descriptive Approach: This is achieved by identifying the general theoretical frame of it, in terms of defining the legal nature of the acts of private military and security companies, and the nature of their relationship with the contracting countries and what is reflected by this nature of international liability of the country on the acts of these companies, in order to identify features and elements of the problem of the international liability of the country for the acts of contracted private military and security companies under the rules of public international law, and in determining the overall shape of the legal nature of this problem, through collecting information about their characteristics and their elements in quality and quantity, and then classification of this information to reach a comprehensive and accurate understanding for the nature of this international liability of the country and its consequent effects.

2. The Analytical Inductive Approach: The nature of this study necessitate the induction the rules of public international law governing the international liability for the act of official bodies, in addition to those legal rules governing the act of private military and security companies, and then interpret and analyze these legal texts and rules, in order to reach a clear and accurate understanding of the issue of the nature of the international liability of the country for the acts of contracted private military and security companies, and to answer all the questions that are raised in this regard.

of private military and security companies.

1. The Legal Nature of Private Military and Security Companies.

Private military and security companies are considered as one of the most important features of development witnessed by the international system after the end of the Cold War. However, it had a significant impact in that it changed the perceptions on military actions and its management during the armed conflict, whether international or internal. Also, this was manifested by changing the characteristics of mercenaries and their military actions, in terms of recognizing them explicitly by some people of the international community under the name of private military contractors. This, however, can be easily pinpointed because they often practice most of the necessary tasks performed by regular armies in military operations.

Consequently, the military and security companies, represented as one of the most important aspects of privatization, included the military sector in many countries that are established through countries contracting with these companies to perform some military and security tasks. United States war in Afghanistan in 2001, as well as that in Iraq in 2003, has formed one of the most prominent aspects of using these companies. Hence, this was a great turning point towards the attention of the international public opinion of these companies, the role played in the armed conflicts (Al-Masdi, 2009, p. 6), and what is arising from its legal nature.

Accordingly, we deliberately want to clarify the legal nature of private military and security companies by identifying the private military and security companies, determine the legal status of the staff of private military and security companies, and then state the international obligations of the private military and security companies based on the following two requirements:

\subsection{Identification of Private Military and Security Companies and their International Obligations}

The concept of private military and security companies emerged from the development of the concept of security privatization. Through this, countries and international governmental and non-governmental organizations seek for the private security companies. Basically, their work is to provide defense security services in order to protect individuals and property, security risk analysis, personnel security training, consultation in crisis management, in addition to providing guards for the protection of public utilities in the country (Ahmad, 2007, p.20).

The development of the security role of these companies made their impact by turning their acts into a military nature, and this was warranted by the nature of the client that the company is dealing with, and what quality of services were associated with them. Therefore, they offer military services that contribute to the operations with the aim of gaining military influence in the armed conflicts field. As a result, they were described as military companies that countries resort to in a particular armed conflict. Also, their classification differs according to the nature of their work (Lilly, 2000, p2).

Hence, the legal problem arose in defining private military and security companies, as expressed by the Green Paper issued by the British Foreign Ministry and Commonwealth Department in 2002. This was after its report on the armed conflict in Sierra Leone, which included a definition of these companies depending on the variety of their offered services; terms of services related to combat operations; support operations; services related to providing military advice, training and arms purchases; and the collection of intelligence, security services, combating crime, as well as logistical support (United Kingdom Foreign, 2002, p10).

In fact, the United Nations has set out to establish an organizing legal framework for the work of private military and security companies. This stems from the recommendation of the general team that specializes in using mercenaries as a means of obstruction of the exercise of the right of people in self-determination. Also, this was confirmed by the need to establish an international governmental working team with an open membership on the international level including representatives and experts from the countries in question. 
Hence, this would help to draft an international convention in regulating the activities of private military and security companies (Ersaan, 2012, p. 493).

Successive reports of this team have addressed the definition of private military and security companies. This was stated in one of these reports that what is intended for private military and security companies is: "a legal entity that provides, for a financial consideration, military services and/or security by natural persons and/or legal entities." The military services mean: "specialized services related to military action, including strategic planning, intelligence, investigations and ground, sea or air reconnaissance, and flight operations of any kind, manned or unmanned, artificial surveillance means, and any kind of knowledge transfer by military applications, material and technical support of the armed forces and other related activities." Furthermore, security services mean: "guarding or armed protection of buildings, facilities, property and persons, any kind of transfer of knowledge through security and policing applications, and the development and implementation of intelligence security measures and other related activities" (United Nations General Assembly, 2014, p. 4-5).

This concept of private military and security companies doesn't differ from what has been addressed by "Montreux Document" concerning the international legal obligations and the sound practices related to the private military and security companies' operations during the armed conflict, which was issued in 17/9/2008. But it, however, did not differentiate between military companies and security companies. These companies were defined as: "private commercial entities providing military and/or security services regardless of the way they are classified, including military and security services, in particular, the provision of armed protection and guarding of persons and property such as convoys, buildings and other places, the maintenance and operation of weapons' systems, the detention of prisoners and the provision of advice or training to local forces and security personnel" (Ammar, 2016, p. 51-52)

It was noted that this approach of the United Nations in the definition of private military and security companies stems from the distinction between private military companies and private security companies. Thus, this is dependent on the different nature of acts and activities of these companies. It was also noted that the definition of these companies adjusted to the work of these companies, and it also determines the nature of their act. If they were numerous or varied, they should not include direct participation in military operations and illegal use of weapons. In addition, their role is limited on passive activity in armed conflicts. Nevertheless, what has emerged from the private military and security companies in armed conflicts on this ground, made the jurisprudence to expand the definition of private military and security companies. This is possible through the inclusion of its work and activity based on the positive side of participating in armed conflicts. They have been defined as: "companies that offer positive nature services, such as military training and offensive combat operations for countries or international organizations" (Brook, 2000, p129).

In the same context, it was said that they are "organizations that their services are beyond passive assistance to parties of a conflict, so as to provide training and equipment for the development of military capabilities to their clients and provide them with strategic feature and the necessary process to manage the armed conflict, including playing the main role in supporting the military forces to clients through the deployment of their private forces on the battlefield" (Attia, 2008, p. 26 and the following pages). With the emphasis on the positive side of the role of private military and security companies in armed conflicts, they were defined from the perspective and the purpose of their establishment. This emerges from the commercial feature enjoyed by these companies, since the motivation behind their establishment is to provide military and security services outside the borders of the country of origin to achieve material profit primarily. Thus, it was stated that "they are multinational trading companies which specializes in providing services that include the ability to use force in a systematic manner and through military means, or to transfer or strengthen this capacity to clients" (Ortiz, 2007, p60).

On one hand, we see that the definition of private military and security companies stems from the nature of their work and what is reflected in determining the legal status of these companies in the light of the rules of international law, the extent of legitimization of such acts, and even with the aim to achieve financial profits due to these acts. On the other hand, they were considered illegal depending on their direct participation in fighting and making their staff carry weapons and use them illegally, and the fact that this converges with the concept of mercenaries, especially with the convergence between the two concepts in terms of the commercial purpose of providing services represented in material profit (Abuel-haj, 2013, p177).

In any case, and depending on the development of the concept of public international law and accompanied by the changing features of the subjects of international law, their role is no longer restricted only to countries. However, they extended to include international governmental and non-governmental organizations. This is not limited to the consequences of the legal status of the acquisition rights, but it also includes bearing international obligations. With the emergence of private military and security companies and their role in international and internal armed conflicts, many problems have arisen in their enjoyment of international legal personality, and what they bear as per international obligations, especially in light of the legal rules of international humanitarian law. 
We noted here that the international legal personality description is limited to countries and international organizations. Thus, this description doesn't apply to multinational companies, which applies in this case to private military and security companies. Also, the United Nations have emphasized this in many of its resolutions that companies generally are not addressed directly to the provisions of international law, such as the resolution No. 1373 of 2001. This resolution was issued after the events of September 11, 2001, which was employed to determine the obligations of countries in combat international terrorism, giving it the power of imposing particular sanctions by virtue of the economic dependency of the people that committed terrorist acts or who try to commit the same.

However, given the nature of armed conflicts and legal rules that are governed and regulated, we found that the staff of private military and security companies ought to oblige away from direct engagement in combat operations. This is done based on the concept of the United Nations for these companies, or they will be stepping outside the scope of the legitimacy of their acts and activities during armed conflicts. On the other hand, it abided by the rules of international humanitarian law according to the national laws of the countries related to their activity. Thus, this could not be achieved without controlling these countries to be subject to individual criminal responsibility for serious violations they might commit or likely to commit. The international legitimacy of this commitment to the staff of private military and security companies are in accordance with "Montreux" Document. Therefore, this included general provisions that ensure commitment to humanitarian treatment and respect for dignity, privacy and human rights standards, and in addition to the rules of using weapons and military equipment (Muna, 2014, p. 91).

This document included the responsibility of companies' managers based on the acts of their staff. Also, this is based on the idea of responsibility of the relationship between managers and their staff. The managers bear the responsibility for crimes that are committed by their staff if they were under their control. This is also applied to managers if they were military or civilians leaders. Also, the managers hold responsibility if the manager was an authorized leader to take disciplinary procedures towards the staff similar to the military forces case (Ersan, 2012, p. 507)

\subsection{Adapting the Acts of the Private Military and Security Companies' Staff}

The rules of international humanitarian law organized the obligations of the conflict militarily parties. The most important among them is respecting the rights of individuals, whether they were civilians or combatants. This is in addition to their referring to some individuals deprived of such protection because of the nature of their acts in armed conflicts, as can be seen in the mercenary soldiers. Given the novelty of the subject of private military and security companies, the problem has emerged in determining the legal status of the staff of these companies, especially those who engaged in armed conflicts directly. Furthermore, the extent of their enjoyment of international protection was also ascertained in accordance with the rules of international humanitarian law in terms of considering them as civilians, combatants or mercenaries. To determine the framework of this problem, we will talk about the nature of the civilians, combatants, and mercenaries in light of the rules of international humanitarian law. This can be seen from the following points below:

1.2.1: Civilians and Combatants: According to the concept of the implications of civilians in the light of the international legitimacy, we can't consider the staff of private military and security companies as related to these categories. This is attributed to the fact that civilians don't constitute a part of the armed forces of the countries of conflict. Article 4 of Geneva Convention of 1949 stated the protection of civilians during armed conflicts to the categories applicable to the description of civilians. These are those who find themselves at a given moment and in any manner whatsoever, in the event of a conflict or occupation, and under the authority of one party of the conflict who are not from their country natives or an occupation country which they are not also nationals. Due to the unclearness of this concept, the ICRC (International Committee of the Red Cross) suggested two definitions of civilians - "Civilians citizens are not part of the armed forces or associated bodies or those who do not participate directly in the operations with a military nature and who do not directly contribute to the activity of war effort". This suggestion was accompanied with a set of amendments and suggestions by members of the Government Experts Conference in its first and second session (Basej, 2010, p. 67).

With the continuation of international efforts in the necessity to clarify the concept of civilians during armed conflicts, the concept of civilians has been reformulated under the First Additional Protocol of Geneva Convention. However, this was interpreted according to the provision of Article 50 thereof, which refers to identifying the categories of combatants and others categories of civilians. Hence, the term "civilian citizens" include the population of all civilian persons residing in the territories of countries in war, and also foreign civilian citizens related to the enemy and the residents of the occupied territories (Mahmoud, 2000, p. 52). Therefore, the additional protocol took the negative concept of civilians. Hence, it shows that civilians are: "persons who are not taking part in hostilities, and do not constitute a part of the armed forces" (Al-Anabki, 2010, p. 287).

Civilians may constitute part of the armed forces, if they were accomplices to the armed forces, as stated in Article 4 of the Third Geneva Convention. They enjoy the same guarantees as the combatants: "They are persons 
accompanying the armed forces without being part of them including civilians, who are among planes fighter staff, war correspondents, catering operators and members of workers' units or services for the entertainment of the military staff, provided that they have a permit from the armed forces".

This category of civilians, constitute one image of the acts of the private military and security companies' staff if their acts were limited to these limits without extending it to include the actual direct participation in military operations (Muna, 2014, 89). Regarding the categories of combatants, Article 43 of the Additional Protocol of the Geneva Conventions identified them. They include the armed forces of a party of conflict, groups, and regular units that are under a leadership which is responsible for the behavior of their leaders before that party, even if that party was represented by a government or an authority that are not recognized by the opponent. For example, armed forces shall be subjected to an internal order to ensure strict compliance to the rules of international law applicable in armed conflicts. The members of the armed forces of the party of conflict shall be considered as combatants. This is because they have the right to contribute directly to the hostility actions. Also, members of medical services and religious bodies are excluded.

1.2.2. Mercenaries: The mercenaries are considered an old modern phenomenon, where communities since old times resorted to hire soldiers from abroad to assist them in wars. Also, regular armies may not have been formed yet in these communities. Mercenaries have been developed even after the regular armies have been formed in the countries, where the nobles in Medieval were keen on their privileges, which made them responsible for the recruiting market of the royal army to feed the royal forces (Borsheet, 2005, p .5).

The twentieth century has witnessed the decline of hiring mercenaries in armed conflicts, where countries decided that their army will be from their citizens only. However, and with the beginning of the emergence of liberation and independence movements, the phenomenon of mercenaries has emerged again. Thus, it has an important and powerful role to play through using them by the colonial powers in the suppression of national resistance movements in colonies that fight for independence. In addition, the intervention of mercenaries in conflicts were often aimed at eliminating the principle of decolonization, which are one action that constitutes a violation of the right of peoples to self-determination and a violation of the principle of the prohibition of using force in international relations (Mahmoud, 1991, p.71).

The armed conflict in Congo has played a major role in the international community's tendency to raise the issue of mercenaries and to criminalize and combat them in accordance with international mechanisms. There were large numbers of mercenaries fighting with the separatists in this war, which called on the Security Council on 31 February, 1961 to take a resolution calling for an action for immediate evacuation out of Congo for any Belgium or foreign military or semi-military existence, as well as political advisers that are not directly associated with the United Nations High Command. In November 24, 1961, the Security Council decided to use all necessary forces to implement this resolution; the troops of The United Nations in Congo began to expel mercenaries (Borsheet, 2005, p. 20).

That was one of the main reasons why the United Nations has called for developing mechanisms to combat this phenomenon. This is because it makes a violation of the right of peoples in self-determination, where the General Assembly of the United Nations in 1968 proclaimed that the way in using mercenaries to confront the movements of national liberation and independence is punishable as a criminal act. Also, the mercenaries themselves are outlaws, and in addition to that, the governments has been asked to implement a legislation that considered the recruitment, financing, and training in its territory as a punishable offense and prohibit its citizens to volunteer in the ranks of mercenaries (Issa, 1997, p. 26).

Despite the international community trend in combating mercenaries, it did not set a specific definition to indicate this phenomenon in armed conflicts. Thus, the proposal of the Nigerian representative to the United Nations is to submit a proposal to the Third Committee of International Humanitarian Conference held in the period between 1974 AD - 1977. This was achieved by inserting the concept of mercenaries to the additional protocol of Geneva Conventions. The Third Working Committee has approved this proposal, and has submitted it to the delegations who participated in the document number (CDDH / 11/GT / 105). In turn, it was agreed upon that these delegations should be stipulated later in Article 47 of the First Additional Protocol of Geneva Conventions.

In details, mercenaries refers to "that person who is recruited to participate actually in hostile actions for the benefit of a country and who is not a citizen or a resident in order to obtain a material benefit far beyond what the army of the country that hired him could obtain". Therefore, the concept of an offense emerged from this significance:

1. If their country was neutral and was sent to fight alongside the enemy, its action is considered to be a violation of neutral rules; their country shall bear the international responsibility, and also those that was not considered as mercenaries.

2. If they are from allied countries and their country send them to fight alongside the enemy, they are not considered to be mercenaries and their country shall bear the international responsibility of violating the rules of the alliance. 
3. If the country expressed its support for the enemy even if it doesn't intervene effectively, but sent the mercenaries indirectly to fight or if they volunteered on their own, they shall not be considered as mercenaries (Al-Fatlawi, 2003, p. 379).

Since the concept of mercenaries emerged from the nature of the relationship between the mercenary who was recruited for the country's benefit and the purpose of fighting in its side, some clarified the concept of mercenaries. However, it was stated that: "A foreign person from the conflict parties, who is recruited voluntarily without being hired by his country in order to participate in hostile actions directly for the benefit of one party of the conflict, despite the absence of a link related to the concerned party that hired him or all of the parties, not a citizenship link or residency in a territory of any of them, and not belonging to the armed forces of the party who recruited him, but he is a professional in fighting specifically to perform combat missions in exchange for an important financial benefit and, furthermore, the financial element exclusively along with the voluntary, private and external nature for a pledge that binds the mercenary with parties of armed conflict is one of the most distinctive characteristics of the definition of mercenary" (Al- Anabki, 2010, p. 274-275). Emerging from considering the mercenary who joins one of the fighter parties in the pursuit of livelihood and as a profession for financial gain, this person is considered as a war criminal from the standpoint of international law, nor does it has the status of combatant. Therefore, the person does not enjoy any privileges, guarantees or rights in case he was under caption. In this case, the mercenaries are no longer from fighters, and this was confirmed by the first paragraph of Article 47 of the Additional Protocol of the Geneva Conventions.

In this way, if the staff of private military and security companies are not considered as civilians or combatants, they are also not considered as mercenaries in light of the international legitimacy definition of these companies and their intention geared towards the development of an organized legal frame. However, under the threat that the private military and security companies in some cases form the historical extension of the phenomenon of mercenaries, it can be said that the private military and security companies were described as mercenaries in the event where they infringe on the provisions of the international legitimacy that organize the rules of international humanitarian law. This entails the potential involvement of its staff in combat activities, direct participation in military actions, and the illegal use of weapons, which converges with the concept of mercenaries in this case.

The United Nations had expressed detailed provisions about the permitted and prohibited activities of these companies. Here, it was stressed that the absence of an international legal organization of the work of these companies, leads to a lack of effective control of countries upon these companies. Thus, it also results to the mixing of the act of the staff of private military and security companies with the act of mercenaries, especially in view of the nature of their activities and potential participation for its staff in combat activities and the activities related to mercenaries. Hence, this constitute a regulatory gaps regarding issues such as the acquisition of private military and security companies' staff weapons, trading with them and their consequences, and the different approach of using power and firearms during the performance of their work. This means that there is the possibility that the staff of these companies carries weapons and also imports them. As a result, there is the need for an international convention to provide rules and unified methods on weapons acquisition, export, import, possession, and use, and to ensure the accountability of the private military and security companies' staff all over the world in the case of illegal acquisition of weapons and illegal trafficking and the use of prohibited force (General Assembly of the United Nations, 2014, p. 30).

Accordingly, we see that the international community deals with private security companies according to the nature of their acts in armed conflicts and the purpose of their participation in these conflicts. In addition, they can determine their legal status from their acts in military operations such as mercenaries in the event of direct staff involvement in fighting in armed conflicts, as well as the financial profit property of this service which they share with mercenaries.

\section{The Nature of International Responsibility for the Acts of Private Military and Security Companies}

Private military and security companies abide by the rules of international humanitarian law during armed conflicts. This commitment is reflected in the contracting countries, which in turn are committed to ensure the compliance of these companies to the rules of international humanitarian law under their international liabilities for the acts of these companies. Thus, they emerged from the obligation of countries to respect the international humanitarian law.

Accordingly, the countries have international responsibility of private military and security companies' violations to the rules of international humanitarian law. In addition, the scope of this responsibility is not limited to be attributed to the acts of private military and security companies, which are described as the direct responsibility of the country. This responsibility extends to include the obligation of countries to exert efforts to ensure these companies respect the rules of the international humanitarian law. This is not only attributed to the responsibility of the contracting country, but also on countries that companies hold their nationality, as well as all the countries that are related to these companies. Thus, this is regarded as the indirect international responsibility. In order to determine all of the legal frames, and the nature of international responsibility for the 
acts of private military and security companies, let us first talk about the definition of international responsibility and its legal basis. Subsequently, this is in addition to the obligations of countries when contracting with private military and security companies, and then searching the responsibility of the country about the acts of private military and security companies based on the following requirements:

\subsection{The Basis of the International Responsibility of Contracting Countries with Private Military and Security Companies}

The rules of international law decide upon a set of obligations that must be adhered to by the countries under its international responsibility. The countries can't be absolute from this responsibility, even if there was a breach in these obligations by others. As long as there was a legal bond between the country and the other breaching party, especially in light of the development of the international responsibility and its legal basis based upon the theory of risk and assume responsibility, this shall raise the problem based on the extent of the applicability of this responsibility upon the country and countries' breaching their obligations when contracting with private military and security companies.

Therefore, we can answer this problem in addressing the basis of the international responsibility of the contracting countries with private military and security companies, through research in the content of international responsibility, as well as by determining the obligations of contracting countries with these companies. This can be seen in the following two sections.

\subsection{The Content of International Responsibility}

The international responsibility is considered as the basic element for any legal system on the international and domestic level. This is because of the basic guarantees which ensure the respect and achieved commitments determined by the legal order on persons. Therefore, what follow is sanctions in case there was a breach in those obligations and non-compliance with their implementation. Here, the international law imposes on its persons enforcing commitments as other legal orders. If a legal subject neglects performing his commitment, he shall bear the subordination responsibility for failing to fulfill his commitment (Meqbel, 2011, p.120-130).

The international responsibility based on three basic principles showed that it is held against a subject of international law subjects, and to civil or criminal law depending on the committed act. This act shall be from the prohibited acts of the international law, despite responsibility maybe achieved through committing acts; thus they are not prohibited by the law, but may result in damages for others (Abu Atiah, 2001, p. 246).

The modern international community adopts the ratification of the international responsibility system when drafting the rules of international law at the Lahai Conference in 1930. Here, the preparatory committee of the conference indicates the concept of international responsibility. They stated: "This responsibility includes the obligation to reform the damage if caused by a breach of the country with its international obligations; it can also include, depending on the circumstances and according to the general principles of international law, the obligation to provide satisfaction for the damaged country in the form of apology provided as an official image and the punishment of the guilty (Al-Sayed, 1985, p. 176). In fact, scholars of international law addressed the issue of defining the international responsibility and in clarifying its implications. Some began to define it based on the fact that countries are the only party that represents international law. Therefore, it was stated that international responsibility is: "a legal order under which the country that was accused of committing illegal act in accordance with the international law is obliged to pay indemnity to the country in which that action was committed against." In the same sense, it was stated that "a legal status is necessary to sue the country who was accused of committing an act or activity to pay indemnity to the damage that affect another country or one of its citizens as a result of this work or activity" (Fadel, 1976, p. 56). In fact, these definitions have been criticized because the international responsibility was limited to countries only. Based on the rules of international law which witnessed development, it no longer considers the country as the only one that represents the subjects of international law. This is because the international organizations have recognized the legal personality in addition to other entities as in the case of national liberation movements. Therefore, we support from our side what others defined the international responsibility as: "the legal penalty of international law for those who don't respect the subject of this law for his international obligations." Based on our justification that this definition includes the country which is also the main international law subject, the international organizations after the recognition of its legal personality within the extend of the objectives and principles established the terms of enjoyment of the right to be the defendant; this was done because of the damage caused by other international subjects or to its own interests (Al-Sayed, 1985, p. 177). Despite the many definitions that have been given about the international responsibility, the common concept is that they are: "a breach of an international obligation of one of international law subjects that require a legal accountability towards the damaged country or affected by the aggression."

The development of international responsibility is not limited to the addressed persons, but it has witnessed developments in terms of legal foundations that it was based upon. Here, many theories have emerged in determining the foundations of international responsibility. Thus, this includes the theory of joint responsibility which appeared in the Middle Ages. This is the first of these foundations, which is based on the accountability of 
the group jointly for the damage caused by one of its members. It is also based on the fact that an individual in the group shall be committed to each member of this group, and it follows that the group would be liable for the crimes committed by one of its members, which could not stop him from committing it (Fadel, 1976, p. 63).

This theory serves a basis for the error theory, which emerged with the development of international law and legal status of the countries. This theory stands for that which must be an error as a result of a breach in an international commitment, whether this error is intentional or unintentional. Therefore, the international responsibility does not undertake unless the country issued a wrong act that damages other countries (Abdel Hamid, 1995, p. 468). This theory has been subjected to many criticisms, especially based on the fact that the law imposes on the legal person the burden of taking responsibility. However, this can only be some sort of responsibility for other act, and the country, as a legal person, practices its acts by natural persons. In case a natural person committed an illegal act, it shall be attributed to the country based on the fact that the will of the natural person is attributed to the country that he represents or is acting for its own interest (Ghanem, 1964, p. 606).

As such, the objective theory has emerged as a basis for the international responsibility, which is based on the illegal acts of the country. It represents a breach of an international obligation, without searching for the will of the country and its intent to commit the offense. This is such that it is limited to the causal link between the activity of the country and the incident violating the international law (Fadel, 1976, p. 123). This theory has been expanded to include legitimate acts without being restricted to illegal acts for the international responsibility. This is based on the risk theory and assumed responsibility, since any act is a harmful act even if it was a legal one which entails the international responsibility. Hence, the act is a key element of the international responsibility, where the country is liable for damages caused by its activities, which are characterized by uncommon danger and which also takes into account the care and caution, and also resulted to a damage that affects others (Ghanem, 1964, p. 503).

We see from our side that despite the agreement on the establishment of an international responsibility on the basis of illegal act, this does not mean it is to be restricted without taking into consideration other theories, which may not occur as a result of an illegal act. Therefore, all these theories shall be taken together as the basis of international responsibility, where one of these theories can't serve as a basis for the establishment of international responsibility without the other, especially since the damage is considered as one of a major international responsibility elements, which may not happen in the light of the error theory. In return, an error may occur as a result of legal act, which denies the international responsibility according to the error theory or the objectivity theory.

\subsubsection{The Obligations of Countries Contracting with Private Military and Security Companies}

The obligations of countries when contracting with private military and security companies includes taking precautionary measures to contract with these companies. As stated initially, countries shall find a good selection of private military and security company to contract with. This would be in terms of availability of appropriate standards, selection of staff and lack of involvement in dangerous crimes, and the methods of compliance with the rules of international law, in addition to compliance with the code of conduct. The country shall specify in the contract the required commitments beginning from the company's commitment to the countries' legislations in which they work inside as well as abide by the rules of international humanitarian law (Michael, 2006, P. 178179).

Initially, the contracting countries shall determine the services that may be contracted to be submitted by the private military and security companies. Montreux Document confirmed this commitment by taking into account some factors by contracting countries, such as if a specific service can make some of the staff of these companies to be directly involved in the hostile actions (Faraj Allah, 2013, p. 186).

Furthermore, the contracting countries shall commit to a set of standards that must be available in the private military and security companies when contracting with them. Montreux Document included these standards, and the most prominent is that these companies shall have all the required permits and the appropriate procedures and standards in regard to the selection of staff. Also, they would inquire about their past activities, training, work rules, and the normal operating procedures. This, therefore, is along with the internal supervision, compliance mechanisms, and the determined sanctions. The document also emphasizes on an important standard in the selection of the company based on its membership in a professional association or its commitment with its code of conduct. Also, its transactions are being subjected to auditing by an independent body. On the other hand, it may include standards to avoid choosing these companies, such as the involvement of the management of company or its staff in serious crimes, or the previous case of a serious professional misconduct or provide misleading information or wrong financial statue or ownership that doesn't enjoy transparency (Cottier, 2006, p. 642).

Furthermore, the contracting countries are committed to private military and security companies to ensure the companies' compliance with the rules of international law. Also, the rules of humanitarian international law impose restrictions on the possibility of countries of conflict to authorize its power for nongovernmental parties. 
Hence, these entities are dangerous to the rights of protected people. In light of this, the contracting countries remain responsible for their obligations in accordance with this law to guarantee its respect and for any failure from the staff of these companies to commit to the standards of this law. Thus, no claim can be drawn by contracting with these companies to elude from its responsibility (Gillard, 2006, p. 549).

This is based upon what is stipulated in the first article of the Fourth Geneva Agreement of 1949, which stated: "Countries undertake to respect these agreements and ensure their respect at all circumstances." According to the article 148 from the above agreement, it is not allowed by any contracting party to elude other contracting party of the responsibility incurred by the contractor or any other responsibility for the violation of this law.

Therefore, countries - at the national level - shall commit to respect the rules of international humanitarian law, including the commitment of the military forces members. This commitment extends to include all persons under its jurisdiction (Joueli, 2005, p. 266). Based on the description of the provisions of international humanitarian law as an obligation to confront all, it is the responsibility of the country to ensure the respect of the implementation of the rules of international humanitarian law. Hence, the country shall not be affected directly with the violation of the international humanitarian law. This is because it is the only one concerned to take the necessary procedure to stop this violation, although other countries have the right to do so (Sasoli\&Antoni, 1999, p. 231).

In the case of private security companies, their activity are associated with several countries and not just those they contracted with, but also countries on whose territories they work on and the country that establishes the company within its territory or the country of origin. All these countries and not just the contracted country are concerned with its compliance with international humanitarian law through legislative and judicial procedures and measures apply at their territories that guarantee the conformity of staff at these companies to international humanitarian law. Furthermore, it also guarantees the prohibition of violations and their suppression (Ersan, 2012, p. 501).

In application, the countries deliberately impose conditions on private military and security companies. This is before working on its territory under special security laws that organize these conditions. The countries may work to adapt these conditions with their political systems, or insert them among the rules of commercial law. Where the reality witnesses otherwise, since there isn't a regulatory legal frame in this regard, the countries are committed to exercise some sort of control and follow up on the activities of these companies. Also, they deliberately investigate the allegations of these companies' violations of the law. Therefore, the country bears responsibility for that, since it has been delegated part of its original functions (Mona, 2014, p. 96).

More precisely, it is based on the responsibility of the countries that private military and security companies hold their nationality. This, therefore, is based on the obligation to carry out a set of legal measures to help them achieve this control element through the adoption of legislation controlling public companies abroad. Also, the countries where the security companies operate on their territory or as a host, must exercise a degree of control and supervision to establish a licensing system that governs the rules of conduct. It may also include a regulatory national work that is applied by imposing conditions on granting licenses to that which the company must adhere to, as well as the identification of sanctions in the case of working without a permit (Al - Khafaji, 2014, p. 1278).

According to the above, we noted that the international responsibility for the acts of the private security and military companies do not have restriction on the contracting countries. Therefore, this responsibility extends to include the country in which the company holds its nationality, where there are obligations in this country. These countries with their different contractual relationship, with private military and security companies, have consequent obligations to ensure the commitment of these companies with the rules of international humanitarian law. Otherwise, they will be subject to international responsibility, which could be directly or indirectly.

\subsection{The Responsibility of the Country of the Acts of Private Military and Security Companies}

There may not be any contracting link between the country and private military and security companies, but the application of the rules of international responsibility and its legal basis. Countries shall bear indirect responsibility for the acts of these companies based on the due diligence standard, which must be adhered to by the countries that have a relationship with private military and security companies. They should also adhere to it even if they were not contracting with them, as is the case of countries where these companies operate on their territory or carry their nationality.

Therefore, the indirect responsibility is based on the responsibility of the act of others, where a country shall bear the responsibility of violating the international law by an international body or other. Thus, the rules of international law require the presence of a special relationship or legal link, specially between the liable country and the perpetrator of act, under which the country shall bear the illegal actions of this body (Fadel, 1976, p. 56).

Within the scope of responsibility for the acts of private military and security companies, the responsibility of the country, essentially based on the contents of the rules of international humanitarian law of provisions, oblige the countries to implement rules immediately or gradually. This shall follow the adoption of many 
legislative, administrative and judicial measures as well as others. This may be necessary for the work of the rights stipulated in the treaties, and may include the promulgate of criminal legislations to criminalize prohibited acts in accordance with the international humanitarian law and their repression, or provide indemnity request before the criminal courts for violations of certain rules and to ensure the effectiveness of indemnity for violating these rules. Countries are deliberate in implementing this through preparatory measures not only limited to military forces, but also include all other persons acting on behalf of the country or under its management and control. Thus, this leads us to include the members of the international private military and security companies employed by the country, even though they were not members of the armed forces (Faraj Allah, 2013, p. 181).

In fact, this responsibility would be applied to the country that the private military and security companies hold sits nationality, as well as the country in which these companies reside in it. Therefore, the responsibility of these countries depends on the consequent obligations through its relationship with the private military and security companies. We have already talked about these commitments earlier in a previous subject of this research, which the reader may refer to prevent repetition.

In a different context, the country bears direct responsibility for the acts issued by its affiliated persons. These include those who are subject to its authority and management. Also, the private military and security companies that are contracting with the country are considered one of these persons and entities, which are subject to the authority of the country's management under the contractual relationship that they have. The meaning of direct international responsibility of the country indicates: "a breach in country's obligations in the international field, whatever the formal source of these obligations whether it was an international treaty, norm or one of the legal principles recognized by the international community or a decision issued by one of the international organizations" (Abdel - Hamid, 1995, p. 412).

Within the scope of the direct international responsibility for the acts of the staff of the private military and security companies, the international law committee has prepared a draft for the rules of public international law related to the responsibility of countries. This was as seen in the draft law of international law committee related to the responsibility of countries for internationally illegal acts $\left({ }^{1}\right)$. Also, this has established some foundations which can have the responsibility of illegal act that are perpetrated by the staff of private security companies to the country. Additionally, the features of that responsibility are determined in one of the following cases (Abu Khawat, 2012, p. 171).

First: The Integration of the Staff of Private Military and Security Companies within the Armed Forces

The acts of these companies' staff in this case are considered acts for one of country's body. In addition, the responsibility can be entitled to the country on the basis of the draft of the first paragraph of Article 4, which stipulated: "The act that is issued by anybody of country's body shall consider as an act issued from that country under the international law provisions."

Furthermore, the armed forces are considered as one of the official bodies of the country. This is because the country's bodies are all individual or collective entities that constitute the organization of the country and that acts on its behalf which include any regional government entity within the country and the central government agencies in the country. The principle of the unity of the country shall consider the acts carried out by all the bodies of the country or the failure of these bodies as acts issued by the country for the purposes of international responsibility. As such, the country shall bear the responsibility for the conduct of the members of the armed forces, their acts shall considered as the country's body acts, and all their actions would be assigned to the country that hired them (Faraj Allah, 2013, p. 154 and the following pages). The country shall bear the acts carried out by private military and security companies if their staff is described as fighters who constitute a part of their armed forces, or when they could be considered as members of the units of volunteers who are part of these forces because they are one of the bodies in which the country bear its responsibility (Ammar, 2016, p. 253).

This was confirmed by Montreux Document because Article 7 stipulates that: "The establishment of contractual relations in itself does not entail the responsibility of the contracting countries, these countries bear responsibility for the violation of private military and security companies or the staff of international humanitarian law or human rights law or any other rules of international law when the violation of this responsibility attributed to the contracting country in accordance with customary international law, especially if the private military and security companies have registered by the concerned country in the regular armed forces, in accordance with its national legislation or were members of the forces or groups or organized armed units under the command of the country leadership."

Second: The Non-integration of Private Military and Security Companies' Staff within the Armed Forces The country has cooperated with mercenaries or the staff of private security companies, without being integrated within its armed forces. Nevertheless, they are working according to its instructions under its authority. So in this

${ }^{1}$ The draft of international law related to the liability of countries for internationally illegal acts of the United Nations Assembly resolution No. (A/ 56/ 589) dated on : 26/11/2001) 
case, referring to the responsibility for the country relies on Article 5 of the draft law, which stipulates that: "It shall be considered an action issued from the country in accordance with the international law as a behavior of a person or entity does not constitute one body of the country's bodies in accordance with the Article 4, but the law of that country authorizes the power of exercising some of the governmental authority terms provided that the person or entity acts accordingly in this concerned case." Also, what was stipulated in Article 8 of the same draft law states that: "Any act issued by any person or a group of persons is considered an act issued by the country in accordance with the international law, if a person or a group of persons act actually according to instructions from that country, or under its management and control."

Perhaps the rule of the International Court of Justice in the Activities Case, Military and Semi Military at Nicaragua 1986 represents a legal international base that can be measured to attribute the responsibility of the country regarding the acts of these entities. Here, the court indicated in its rule that the United States was considered liable for the acts of Contra Fighters, based on the fact that the United States performed the planning, directing, and supporting of those fighters (Nicaragua v. USA, Merits, ICJ Reports, 1986, P.113).

Accordingly, we noticed that the contracting country with private military and security companies shall be liable for the acts of their staff, which form violation of the rules of the international humanitarian law and the human rights law, even if those staff are not a part of the armed forces, and if also it was proven that the staff of these companies perform their actions based on the instructions of this country or under its public but not the actual control (Al-Masdi, 2009, p. 127). In light of the foregoing, the company exists as a link between the country and the contractors that may cut plausibly the link of the country with them. Also, the impossibility of these countries to directly address the rules of the international humanitarian law will not preclude without attributing the responsibility for those committing offences of the international humanitarian law to the countries that hired them. This is done through these companies that benefit from their activities, as long as they perform tasks that are originally a part of the country's tasks in an armed conflicts (General Assembly of the United Nations, 2001, p. 59).

In fact, countries often resort to organize the activity of private security companies working for their own account to impose armed forces relationship with contracting companies during what is so-called contracting officer. He is a governmental employee from the contracting country and he has the direct power to contract with the company in order to represent the armed forces of the country. Nevertheless, his role is to control the companies' commitment of contracting conditions, and he doesn't achieve a direct link between military leaders at armed forces of the country and the staff of the company. As a result, the contracted staff in these companies was not subjected to the authority of their superiors from the staff of the company (Joueli, 2005, p. 267).

In general, we noted that the contractual relationship between the country and the private military and security companies is regarded as an explicit authorization of tasks for the private military and security companies. Furthermore, the contract is also considered as some sort of instructions to put the company under the management and control of the country. Here, it shall be proven that there is an existence of a direct relationship of the country with the already harmful reality. This is because the existence of a bond between the country and these companies is not sufficient once contracted with the company only.

In light of the foregoing, the contracting country with the private military and security companies shall be liable for the acts of private military and security companies' staff which constitute a violation of the rules of international humanitarian law and human rights. Therefore, it is not only based on the proportion of these behaviors to it, but also the international responsibility extends to include the responsibility of the country based on the country's breach of its obligations and its failure to exercise due diligence to prevent such violations. This basically can be seen in the case of failure to enact legislations and codes of conduct which these companies must follow. Consequently, this country exercises its competences during the armed conflict. On the other hand, it does not provide awareness about these companies and their staff based on their obligations. This, therefore, is in accordance with the rules of international humanitarian law and human rights law. This is in addition to the lack of training on how to implement these commitments, especially if the staff of these companies' tasks related to dealing with protected categories is in accordance with the international humanitarian law (Williamson, 2008, p190).

\section{The Impacts of Country's Responsibility for the Acts of Private Military and Security Companies}

The country shall commit the indemnity for the damage caused towards the other subjects of international law when performing its international responsibility. This is such that the country or the legal or damaged subject is entitled to resort to international justice to proclaim the reform of this damage by the country that led to the damage.

Accordingly, this is after identifying the liabilities which are arranged by the rules of international humanitarian law on acting parties at armed conflicts as being on direct or indirect relationship with the violations and crimes committed by the staff of private military and security companies. However, the rules of international humanitarian law paired the responsibility of countries concerning the violations of this law with the acts of armed forces. This is regarded as one of their bodies that led us to inquire about the possibilities of 
attributing the violations of individuals working at these companies to the country, which was stipulated in Article 91 of the First Additional Protocol of Geneva Conventions (Ersan, 2012, p. 1-502).

Initially, the issues of judicial authority competence into violations of private military and security companies were raised. This is aimed at determining the attributing of these violations to the countries, and thus its consideration of the claims for indemnity submitted by the damaged international legal subjects damaged by these violations. It also determines the extent of these claims in the light of international responsibility. On the other hand, the question is raised concerning the nature of indemnity that the country - companies who violate the rules of international law-is committed to.

To answer these questions, we searched the content of international indemnity claims and jurisdiction consideration, and then look at the nature of reparation of damages resulting from companies' violations of the rules of public international law. Thus, this can be seen in the following two requirements:

\subsection{The Content of International Claims of Indemnity and their Jurisdiction Consideration}

First, we will talk in this part of the study in the content of international claims and their scope in international responsibility. After then, we will look into determining judicial jurisdiction consideration based on the country's responsibility for the violations of private military and security companies in the following sections:

\subsubsection{The Content of International Claims and its Scope in the International Responsibility}

The international commitment is linked with the international responsibility, where the consequent breach of the international obligations arises in the emergence of a new legal bond between the international law subject who breached his obligation or failed to fulfill it. It also considers the legal person who was damaged because of this breach. As a result, the legal person who breached the obligation to remove what resulted to this breach as well as the other legal person is entitled to claim the first legal person for indemnity. Thus, this was expressed by the permanent International Court of Justice in its judgment issued in 26/July/1927, which stated: "The principles of international law mean that the breach of an obligation of one party is obliged for an appropriate indemnity, and that this indemnity obligation is a natural complementary to any international treaty without any need to state on" (Sultan et al., 1978, p. 300).

Since the international responsibility in general arises from the violation of the rules of international law, and cause damage to others, the impact of the consequences arising from this violation is the reparation of the caused damage, which is either in financial indemnity or as a settlement. The legislative (Fiqh) has expressed this indemnity as an effect of the international responsibility, saying that the main legal result for international responsibility is the moral and physical indemnity for the caused damage. As such, we found that the most recent important developments in international law is that it can't deprive people of their means. Thus, this idea contained in the article of the International Covenant on Civil and Political Rights, and the logical result for this idea shows that if any international organization violated this right, it shall compensate as an indemnity to the damaged party (Al-Jundi, 1990, p. 35).

Accordingly, the certainty of the international responsibility of the country for the violation of the rules of international law only arranges the civil responsibility that is represented in repairing the damage caused by these violations. This basically is the case since the international community does not allow the damaged party to claim only according to this civil responsibility. Therefore, it is difficult to imagine the implementation of criminal responsibility in confronting this country and what is the result of the sanction (Ibrahim, 1997, p. 651).

The international draft law committee related to the responsibility of countries for international illegal acts devoted this trend, in accordance with Article 42 thereof, which stated: (1). It is not allowed for a damaged country to take countermeasures against a country that is liable for an international illegal act, unless for the sake of inducing the country to comply with the obligations stipulated in the second chapter. (2). Countermeasures are limited to non-fulfillment, at the present time, with the international obligations of the country taking measures towards the liable country. (3). The countermeasures, as far as possible, shall be taken in a way to permit the resumption of fulfillment of the concerned obligations. The draft itself also stressed that the responsibility of the country focused on reparation of losses. Article 31 stipulates that: "1. The liable country shall have an obligation for entire reparation of the loss caused by the international illegal act. 2 . The loss includes any damage, whether physically or moral, caused by the international illegal act committed by the country."

As such, the obligation of the liable country of the entire reparation associated with the loss resulting from the international illegal act, and the concept of loss indicates here to any damages caused by that act, whether physical or moral. Physical damage means the damage that affects the property of the country or its citizens or its other interests, which its amount can be determined in financial terms, while the moral damage refers to the damage that relates to emotional pain and personal suffering or personal humiliation (Faraj Allah, 2013, p. 231232).

Therefore, we affirm that the international claim according to the international responsibility does not take the quality of punishment, as it is being limited to damage indemnity. This is attributed to the fact that the resulted effects of the international responsibility remain in the civil scope, and then the responsibility of the illegal act is limited only to repairing the damage and fixing the damage as it was before the illegal act. On the 
other hand, it involves paying an amount of money equivalent to physical indemnity with the appropriate settlement provided by the country that committed the illegal act to the damaged country. This is done this way because the country is not a natural person, but a moral person. However, the moral person can't be a criminal because the acknowledgment and the will are limited to natural persons, in addition to the lack of public authority that can impose punishment on the aggressor country. The international judiciary has issued several judgments that considered that there is no punitive feature for the international responsibility, and that the legal nature of the indemnity is limited to repairing the damage.

\subsection{2: Jurisdiction into a Country's Responsibility for the Violations of Private Military and Security Companies}

It shows that the country is obliged in its claim toward the aggressor country to go through the legal methods, whereby the international judicial authority is considered as one of the most important of these methods. This, however, plays an important and significant role in establishing the principles of international law, since it specializes in considering unlimited disputes, thus contributing to the establishment of many of the international legal and precedents rules (Al-Aneen, 1979, p. 114).

As such, the international law subjects resorted to claim indemnity according to the international responsibility through specific channels in accordance with the rules of international law represented by the International Court of Justice. Therefore, this is one of the principal bodies of the United Nations. This as well is regarded as the primary judicial body for this commission. Additionally, its progression was identified in accordance with its statute annexed in the Charter of the United Nations, which all members of the United Nations' countries are part of. The International Court of Justice has an important and significant responsibility in resolving international disputes, as this court was established to achieve the supreme goals of the United Nations that are stipulated in the first article of the Charter. This also is represented in the principles of justice and international law, and resolving international disputes which may lead to a violation of peace.

The jurisdiction of the International Court of Justice is determined on the basis of a personal standard, which means any standard that is suitable to be a part of the suit. Also, this jurisdiction is determined based on substantive standard, and it consider the matters that can serve as a subject of a lawsuit filed before the court (AlDaqaq, 1990, p. 392 and the following pages).

\section{First: The Substantive Jurisdiction of the International Court of Justice}

The Article 36 of the statute of the International Court of Justice stressed on the substantive jurisdiction of the International Court of Justice, including the consideration of all international disputes. Thus, this is such that there is no incident that constitutes a violation of international obligations, in addition to considering the nature and the limits of the necessary reform for the violation of an international obligation.

Nevertheless, the consideration of the International Court of Justice in considering these international disputes will not be conducted unless by the consent of the related countries, either prior to or after the dispute. Hence, this is what distinguishes the international judicial system from the internal judicial system. This is because the countries have sovereignty, and this sovereignty blocks between the country and any other international authority only with its consent and satisfaction (Almosa, 2003, p. 21 and the following pages). Furthermore, the given jurisdictions of the International Court of Justice, for consideration, do not take the imperative prescription. This is due to the fact that the obligation of countries of the court's jurisdiction did not happen only through a voluntary permission from its part. In confrontation with a country, it accepts the obligation in the same way and that is what makes its will a role that can't be denied in this regard. As a result, it is difficult to say that the jurisdiction of the court is an imperative jurisdiction (Amer, 1995, p. 396).

The provision of Article 36 of the statute of the International Court of Justice, considered that the Court's jurisdiction is compulsory in the case that the countries which are members of the statute has explicitly and willingly declared thereby. Therefore, the jurisdiction of the International Court of Justice is an optional basis and is not compulsory, as long as it is based on the will of the concerned countries. Accordingly, the will of the country can be expressed by resorting to the "Court" in order to resolve legal disputes with another country with one of the following methods:

First: Special Agreements Method: In accordance with this method, two or more countries can agree to refer to a standing dispute among them to "The International Court of Justice" by signing an agreement among them to this purpose. In such a case, the court is entitled to the consideration of this dispute once it received a notice of the special agreement signed between the concerned parties.

Second: Pre-Pledge Method: Normally, countries provide this kind of pledge in the bilateral or collective treaties that are contracted with other countries. This, however, is in addition to the pledges that may be issued by them in the era of "Permanent International Court of Justice."

Third: Optional Item Method: The concerned countries of the statute of the International Court of Justice may give a broad pledge any time by declaring its acceptance of the imperative jurisdiction of the Court towards any country which accepts the same pledge in matters related to the interpretation of a treaty, or any matter of international law issues, or with any incident that resulted in the emergence of an infringement upon an 
international obligation, and finally in the process of the nature and extent of indemnity resulting from such infringe.

For that, the second paragraph of article 36 of the statute of the court stipulated that: "It can be conditional or unconditional, but the vast majority of statements are either conditional or with some reservations such as reciprocity of treatment, or limited duration or determine the nature of the included disputes."

\section{Second:- The Personal Jurisdiction of the International Court of Justice}

Article (34/1) of the Statute of the International Court of Justice stipulated that: "Countries alone shall have the right to be parties in the proceedings before the Court."Thus, the right to resort to the Supreme Court of Justice is limited only to the countries without the international organizations and individuals, although there are rules of public international law that addresses the individuals directly. Hence, this is despite their contribution in the judicial proceedings before other international courts other than the International Court of Justice (Abu Heef, 1971, p. 275).

Accordingly, the litigating parties are not individuals, but only countries are entitled to carry a lawsuit before the International Court of Justice. The intended countries are members of the United Nations, in addition to a country that is not a member in the United Nations, but that participated in drafting the law of the court, which is Switzerland, as it is entitled to carry a law suit and attend meetings (Al-Daqaq, 1990, p. 394)

In this regard, Article 35 of the Statute of the International Court of Justice indicates the cases of countries that are not a member of the statute of the International Court of Justice, or a member of the United Nations. Nevertheless, the decision is due to the Security Council, which sets the conditions under which these countries can carry a lawsuit before the International Court of Justice, taking into account and not breeching the equality of litigants before the court.

Regarding the nature of the decision of the court, Article 55 of the Statute of the International Court of Justice confirmed that the judgment in the lawsuit is issued based on the majority opinion of the members of the court. In the case of equality of votes, the side in which the president is a member in shall be considered. In accordance with Articles 60 and 61 of the same statute, this judgment is a final one and does not accept the appeal, but it may re - consider the case, in specific cases, such as discovering a decisive incident in the law suit in the verdict. However, this was unknown to the court or the party who wishes to reconsider without neglecting. Here, re-consideration will be done within six months from the time of the discovery of the new incident. In all cases, the reconsideration is not allowed after ten years from the date of the judgment.

\subsection{The Reparation of the Losses Resulting from the Violations of the Private Military and Security Companies}

The concept of reparation losses refers to a set of measures undertaken by the country that violate the rules of international law in order to repair the damage resulting from this violation. Therefore, the impact of the international responsibility through illegal act is a commitment to repair the damage either by repairing the damage as it was before the harmful act, or by indemnity or appropriate settlement.

This was stipulated in Article 34 of the draft of international law committee related to the country's responsibility of illegal acts, which stipulates that: "Full reparation for the loss caused by the internationally illegal act by response, indemnity and settlement, either singly or in combination." Subsequently, we deliberately clarify images and forms of reparation of losses resulting from violations of private military and security companies in the range of international responsibility based on the following points:

\subsubsection{The Response (Repair the Damage as it was Before the Harmful Act)}

This form of reparation of losses finds its legal justification from the peace treaty concluded after the Second World War, which did not recognize the annexation procedures carried out by the Axis powers during the war (annexation of Austria, Czechoslovakia, Ethiopia and Albania). Emerging from this principle, all properties were returned to the mother country that was transferred to the territory of the conqueror country using coercion and force (Al-Jundi, 1990, p. 61). "Repair the damage as it was before the harmful act as a result of the international responsibility" means to reconstruct the situation to its former origin, which it was before committing the illegal act which caused damage to others, if it was permissible and possible. This means serves as a material reform of the damage, and may not be reversible to other means, unless this is not possible (Nada, 1986, p. 193).

Therefore, it shall first resort to this mean if available. This is because it is considered to be effective and influential based on the issue of reparation of damage. It also helps to avoid the occurrence of any breach of the rules and provisions of international law. The jurisprudence of international law has emphasized this. What the French jurisprudence makes from reconstructing the thing to its natural way is the probable model. Also, it is regarded as a public duty in the frame of contracts concluded between the subjects of international law, especially among foreign countries and companies (Al-Jundi, 1990, p. 61).

Therefore, it is definite to resort to the above mentioned means, as this is consistent with the natures of things. Also, this leads to the restoration of the situation as it was, and thus the damage will be vanished and the damaged shall have his stolen right. The balance that was in a state of disturbance has been achieved due to the commission of international illegal act. 
This would happen in accordance to the content of international responsibility, which refers to the need to repair the damage. This includes repairing the damage as it was before, in the case that the violator of the rules of international law has committed this offense and he knows that we can't recognize his commitment of indemnity rather than repair the damage as it was before. This, however, is attributed to the fact that it encourages the countries to attack each other as they can pay indemnity (Abu Skhuila, 1981, p. 256). The draft of the International Law Committee about the responsibility of countries for their internationally illegal acts dedicated this form of reparation of losses under Article 35 thereof. Thus, this stipulates that: "The country that is liable for an internationally illegal act obliged to response, as to repair the damage as it was before committing the internationally illegal act, provided that this response as far as: (a) Is not materially impossible. (b) Not involve a burden that is not suitable with the benefit deriving from the response instead of indemnity."

International practices and the international judiciary had witnessed the judgment of the perpetrator who committed the illegal act by compelling him to repair the damage as it was. These international practices can be cited, although it is generally the responsibility of the country and not the international organizations. Additionally, the international responsibility is based on international organizations as can be seen in the case for the country and this applies to it.

Examples of such practices are the fifth rule of the recommendation of the General Assembly of the United Nations as enshrined in its resolution No. (3314). It defined the aggression in modern international law according to which the aggressor can't reap the fruits of its aggression. Also, the consequences of this idea is a logical outcome that says that the aggressor country shall restore everything that it captured during its aggression against the territory of other countries (Al-Jundi, 1990, p. 62).

Furthermore, the Permanent Court of International Justice has judged in the case of Chorizo Factory that the first means that shall be resorted to, when one of the parties violate its obligations stipulated in the treaty, is to repair the damage as it was before and should be considered as a natural indemnity for the illegal act (Nada, 1986, p.195).

3.2.2: Financial Indemnity: The financial indemnity is regarded as one of the most actively and widely spread images on the subject of repairing the damage. It means to pay an amount of money which represents the size of the actual damage. Also, the financial indemnity shall be resorted to in case it became impossible to repair the damage as it was before. The amount of the indemnity shall be determined by the consent between the conflict parties or through arbitration or the judiciary and, mostly, the amount of indemnity will be agreed upon based on negotiations that take place between the concerned parties (Al-Sayed, 1985, p. 188 ).

In the case where the indemnity was estimated by the international judiciary, the international judge here, and despite what he has of discretionary powers in determining the amount of indemnity, he is committed with the provisions and rules of international law. This, therefore, governs the relationship between the prosecutor and the international organization (the defendant). Moreover, it is not the rule of law that governs the relationship between the organization that caused the damage and the individual who was harmed, since the international responsibility proceeds as a general rule before the international judge between two subjects of public international law, whether between two countries or between countries and international organizations or between two international organizations (Nada, 1986, p. 196).

So, the indemnity is repairing the occurred damage in the form of amount of money, or offering material things accepted by the damaged person or judged by competent authorities. Indemnity shall be resorted to if the reparation of damage, as it was before, was impossible, which includes what the prosecutor has compensated the loss with and what he is supposed to gain as profit (Abu Sukhailah, 1981, p. 359). The advantage of financial indemnity is intended to compensate the damaged for all the results of this act, which caused the damage. Therefore, this includes the compensation of his loss and what is supposed to be the expected gain or profit as a result of illegal act, in addition to other damage elements that varies from one case to another (Nada, 1986, p. 195).

The International Draft Law Committee related to the country's responsibility for the illegal acts pointed out this type of indemnity, as stipulated in Article (36) thereof. Hence, this indicated that:

(1). The country that is liable for an internationally illegal act has an obligation to compensate for the damage that resulted from this act, in case of not repairing this damage by response. (2). The indemnity includes any damage that can be assessed financially, including what is lost or gained, as far as this gain is certain.

Third: Settlement: The settlement is considered as appropriate indemnity when the illegal act attributes to the international organization doesn't cause any physical damage. Then, the non-material and moral damages affect third parties as a result of this act, which the financial indemnity is not appropriate or inadequate to repair it (Nada, 1986, p. 198).

In fact, the apology has been understood as a political pattern of repairing the damage, it is difficult to understand it legally, and it leads to a large misuse and is often excessive. Therefore, we may find that it has been deleted from the drafting of international law conference, held in 1930. Also, it was rejected by the rapporteur of the international law committee decision of the jurist (Rabijan) as he rejects the punitive feature of 
apology (Al-Jundi, 1990, p. 65). However, in fact, the apology came within settlement images in the project of the International Draft Law Committee related to the responsibility of countries for the illegal acts. Here, Article 37 stipulated that: "(1) The country which is liable for internationally illegal act shall oblige to present a settlement for the loss that is resulted of this act if this loss can't be repaired by a response or indemnity. (2) The settlement may take the form of acknowledgment of the breach, or an expression of regret or a formal apology, or any other appropriate form. (3) The settlement shall be proportionate with the loss, and shall not take a form of humiliation for the liable country."

\section{Conclusion}

The concept of private military and security companies emerges from the nature of their work and what reflect the legal status of these companies in the light of the rules of international law in terms of the extent of legitimization of these acts, although they are aimed at financial profit as a result of these acts. On the other hand, the extent of considering them as illegal is based on their direct participation in fighting and their staff holds weapons. Also, they use them illegally because they are close to the concept of mercenaries, especially with the convergence of the two concepts in terms of the commercial purpose of providing services represented in financial profit.

In fact, the international community dealt with private security companies depending on the nature of their work in armed conflicts and the purpose of their participation in these conflicts. Also, their legal status can be determined from their activity in military operations. According to the general concept of private military and security companies in the light of international legitimacy, the staff of private military and security companies are not regarded as mercenaries as a general rule. However, it is under what the private military and security companies constitute in some cases from a historical extension of the mercenaries phenomenon. It can be said that the private military and security companies are described as mercenaries in case they depart from the provisions of international legitimacy governing the rules of international humanitarian law, such as the potential participation of their staff in combat activities, direct participation in military actions, and illegal use of weapons. Thus, this converges with the concept of mercenaries in this case. This was expressed by the United Nations in its detailed provisions regarding the permitted and prohibited activities of these companies, which mixes with the work of mercenaries, especially in view of the nature of their activities and potential participation of their staff in combat activities and activities related to mercenaries. In this regard, the international legitimacy confirmed in accordance with Montreux Document on general provisions include the obligations of private military and security companies. This also includes the ensuring of compliance with humanitarian treatment and respect for dignity, privacy and human rights' standards, in addition to the rules of the use of weapons and military equipment. Thus, it is the responsibility of private military and security companies and their staff commitment to the inadmissibility of actual direct participation in combat operations that is based on the concept of the United Nations for these companies. Countries ensure the implementation of private military and security companies for these obligations. Under the international responsibility for the acts of these companies, it is not limited to the contracting countries with these companies or countries that companies operate in their territory. Nevertheless, it extends to include countries that the military companies hold their nationality.

In general, this international responsibility emerged from the entailing of obligations through itsrelationship with the private military and security companies, such as country's imposition on private military and security companies' conditions in accordance with a legal frame which governs the work of these companies. This happens before these companies start their acts on its territory, in addition to the country's exercising of a sort of control and follow up on the activity of these companies. This is done so as to ensure the commitment of these companies to the rules of international humanitarian law.

When countries breach these obligations, they shall bear the international responsibility, which entails the obligation of countries with civil responsibility represented in reparation of losses resulting from violations of private military and security companies. Furthermore, this is enshrined in the International Law Committee based on its draft on countries responsibility for their illegal acts.

\section{Recommendation}

The rules of international law do not contain international legal rules governing the work and activities of these international companies and that refers to a legal gap in the international norms. We recommend that the United Nations Organization issues the establishment of legal controls and standards or an international convention for regulating the activities of international military and security companies, including all legal aspects of the activities of security and military companies.

The rules of international law and the draft of international convention on international responsibility of States do not contain legal norms dealing with international liability for international legal violations committed by such companies. Therefore, it is recommended that the international society is in a bad need to clear and specific international legal norms and criteria that deal with the responsibility of international security and 
military companies. In the meanwhile, these international conventions must contain legal norms and rules that deal with the responsibility of States that allow these companies to practice their activities on their territories and allow licensing these companies.

\section{References}

First: Arabic References

-Adel Abdullah Al-Masdi (2009). Private Military and Security Companies in the Light of the Rules of International Law, Dar Al-Nahda Al-Arabiya, Cairo.

-Abd Al-Ghani Mahmoud (2000). The Protection of Victims of Armed Conflicts in International Humanitarian and Islamic Law, the International Committee of the Red Cross (ICRC), Cairo.

-Ala'aAbd Al-Hafiz Al-Nisr (1997). Mercenaries, the Phenomenon and Development, Journal of the National Guard.

-Ali Al - Khafaji (2014). The Legal Regulation of Criminal of Private Security Companies in Iraq: An Analytical Study, Journal of the University of Babylon: Human Sciences, Vol. No. (22), Edition (6), Iraq.

-Ali Sadiq Abu Heef (1971). Public International Law, Knowledge Facility, Alexandria.

-Amir, S. (1995). An Introduction to General International Law, Dar Al Nahza Al Arabeya, Cairo, $2^{\text {st }}$ Edition.

-Al-Moosa, M. (2003). "The Judicial Function of International Organizations, Dar Wael Publishing.

-Al-Sayed Abu Atiah (2001). The International Sanctions between Theory and Application, The University Culture Institution, Cairo.

-Ayman Abu Al-haj (2013). The applicability Of The Concept Of Mercenary On Military And Security International Companies Under The Rules Of International Law, European Scientific Journal June, vol.9, No.16.

-FuadShubat\&Abd Al-Aziz Shukri (1966). The International Judgment, Al-Matbah Al-Jadida, Damascus.

-Faisal Faraj Allah (2013). The Responsibility of Country for the Violations of International Private Companies, Military and Security in the light of International Humanitarian Law, Al-Halabi Law Publications, Beirut.

-Gboli Mona (2014). The Legal Aspects of the work of Private Military Companies in the Light of International Human Law: The Privatization of War, Journal of Law and Human Sciences, No. (19), ZianAshour University, Algeria.

-General Assembly of the United Nations (2014). The Report of the General Team Aimed at Using Mercenaries as a Mean of Violating Human Rights and Impeding the Exercise of Peoples' Right in Self - Determination, Document Number (A/HRC/27/5).

-Ghassan Al-Jundi (1990). The International Responsibility, First Edition, Al-Tawfiq Printing Press, Amman.

-Hassan Al-Haj Ali Ahmad (2007). The Privatization of Security: The Growing Role of Private Military and Security Companies, the Emirates Center for Studies and Strategic Research, a Series of Strategic Studies, No. 123.

-Ibrahim Al-Ani (1976). Resort to Arbitration, $1^{\text {st }}$ Edition, Dar Al-Fkr Al-Arabi, Egypt.

-Ibrahim Ali (1997). International Rights and Duties in a Changing World, Dar Al-Nahda Al- Arabiya, Cairo.

-International Law Committee Report concerning its fifty second session agenda, the yearly

-International Law Committee, second vol., second part 2001.

-Jamal Nada (1986). The International Organizations Responsibility in the Field of International Function, the General Egyptian Book Organization, 1986.

-Khadija Ersan (2012). Private Security Companies in the Light of International Humanitarian Law, University of Damascus Journal for Economic and Law Science - Vol. 28, $1^{\text {st }}$ Edition, University of Damascus, Damascus.

-Michael Cottier (2006). Elements related to Contract with Private Military and Security Companies and Organizes its Work, the International Journal of the Red Cross, Vol. (88), Edition No. (863), Switzerland.

-Maher Abu khowat (2012). The Legal Status of Mercenaries and the Staff of Private Security Companies during Armed Conflicts, Journal of Studies: Science and Shari'a Law, Vol. 39, No. 1, University of Jordan, Jordan.

-Majdi Mohammad Issa (1997). The Mercenaries: Private Sector's Armies on Demand, the National Guard Journal, Edition No. (148), Riyadh.

-Mohammad Abu Skhalia (1981). The International Responsibility for the Implementation of United Nations Resolutions, Part I: The General Theory of International Responsibility, $1^{\text {st }}$ Edition.

-Mohammad Al-Daqaq (1990). The International Organization, Al-Dar Al-Jameaiah, Beirut.

-Mohammed Hafez Ghanim (1964). The Principles of Public International Law, NahdatMasr Printing Press, Cairo.

-Mohammad Sami Abd Al-Hameed (1995). The Proceedings of Public International Law, Second Part, The International Rule, Al-Dar Al-Jameiah, Alexandria.

-Mohammed Saeed Salem Goueli (2005). The Special Nature of International Humanitarian Law Agreements, Part I: The International Humanitarian Law: Prospects and Challenges, Al-Halabi Law Publications, Beirut. 
-MusbahMeqbil (2011). The International Employee and the Extent of the International Organization Responsibility about its acts, Dar Al-Nahda Al-Arabiya, Cairo.

-Mustafa Attia (2008). Private International Military and Security Companies, Dar Aartak for Printing and Publishing, Cairo.

-Nizar Al-Anabki (2010). The International Humanitarian Law, Dar Wael for Printing and Publishing, Amman.

-Nawal Basaj (2010). The International Humanitarian Law and the Protection of Civilians and Persons in times of Armed Conflicts, Al-Halabi Law Publications, Beirut.

-RashadAref Al-Sayed (1985). Principles of Public International Law, Amman.

RadwaAmmar (2016). The Role of Private Military and Security Companies in the Peace Process: Political and Legal Study, Dar Al-Nahda Al-Arabiya, Cairo.

-Sultan et al. (1978). The International Public Law, Dar al-Nahda Al-Arabiya, Cairo, p. 300.

-Sameer Mohammad Fadel (1976). The International Responsibility for Damage Caused by Using Nuclear Energy at Time of Peace, A'lam Al-Kutub, Cairo.

-Suhail Hussein Al-Fatlawi (2003). Al-Waseet in the Public International Law, Dar Al-Fikr Al-Arabi, $1^{\text {st }}$ edition, Lebanon.

-Wilfred Borchat (1984). Mercenaries in Africa, Translated by Joseph Abdullah, The Arab Foundation of Studies and Publications, $1^{\text {st }}$ Edition.

\section{Second: Foreign References}

-Carlos Ortiz (2007). The Private Military Company: An entity at the centre of overlapping spheres of commercial activity and responsibility, in Jäger, Thomas, and Kümmel, Gerhard (eds). Private Military ad Security Companies. Chances, Problems, Pitfalls and Prospects. Wiesbaden, VS Verlag.

-Chiara Gillard Emanuela (2006). Business goes to war: private military and security companies and international humanitarian law, IRRC, Volume 88, Number836, September.

-Damian Lilly (2000). "The Privatization of Peacekeeping: Prospects and Realities," Disarmament Forum, No.3.

-Doug Brook (2000). Messiahs or mercenaries? The future of international private military services,

\section{International Peacekeeping, v7, No 4.}

-Nicaragua v. United State of America (1986). Merits, ICJ Reports at 112,215. accessed on 3rd March, 2011, http://www.icj-cij.org/docket/files/70/6503.pdf.

-MishaelCottier (2006). Elements for Contracting and Regulation private and military companies, IRRC Vol.88, No863, Sept.

-Sasoli, M. \&Bouvier, EA. (1999). How does law protect in war, volume, ICRC, Geneva.

-United Kingdom Foreign and Common Wealth Office (2002). Private Military: Options for Regulation, HC 577, London: The Stationery Office, 12 February.

-Williamson, A of Jamie (2008). Status And Obligations Of Mercenaries And : private Military / Security Companies Under International Humanitarian Law, In SabeloGumedze (ed.): Elimination Of Mercenarism In Africa, A New Ticket Support Need For Continental is of a Approach, the ISS Monograph series . No 147.

-Yearbook of the International Law Commission, 2001, vol. II, Part Two, Text adopted by the International Law Commission at its fifty-third session, in 2001, and submitted to the General Assembly as a part of the Commission's report covering the work of that session $(\mathrm{A} / 56 / 10)$. 